\section{Conjugated linoleic acid supplementation does not improve boar semen quality and does not change its fatty acid profile}

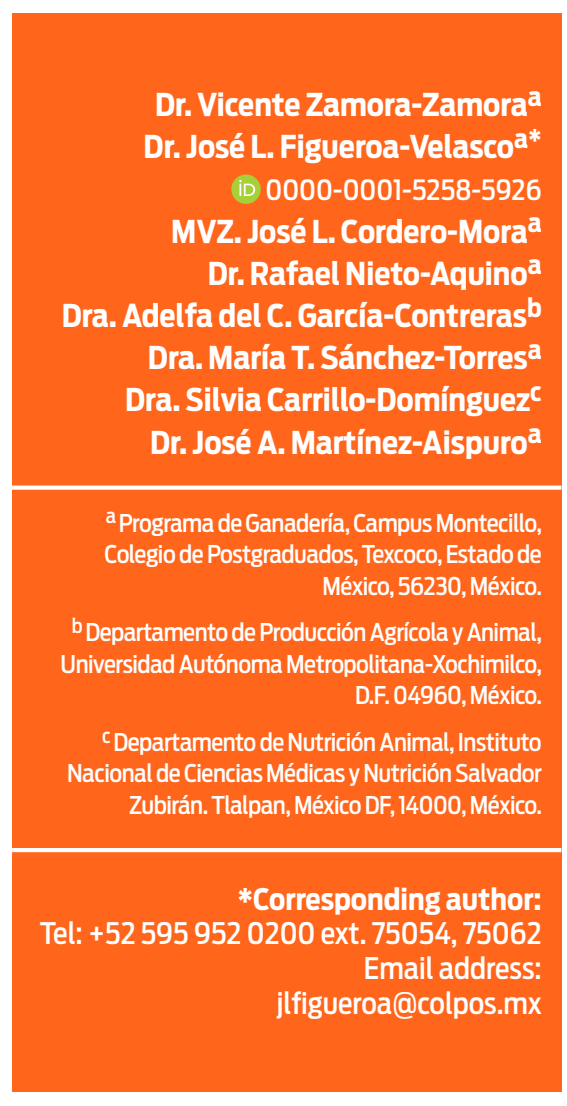

Received: 2016-05-31 Accepted: 2017-06-07 Published: $\quad 2017-07-31$

Additional information and declarations can be found on page 12 @Copyright 2017
Vicente Zamora-Zamora open access $\boldsymbol{\gamma}$

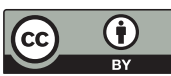

Distributed under Creative Commons CC-BY 4.0

\section{Abstract}

The aim of this study was to evaluate the effects of adding conjugated linoleic acid (CLA) to boar diets on semen production and characteristics, the fatty acid profile of spermatozoa, and on testicle and boar carcass parameters. Ten lean-type terminal-line (Yorkshire $\times$ Landrace $\times$ Pietrain) adult boars were randomly assigned to one of two treatments: (1) a control diet and (2) the same diet with $1 \% \mathrm{CLA}$. The research was conducted in Mexico, and animals were exposed to ambient temperatures between 13.5 and $26.3^{\circ} \mathrm{C}$. Boars were ejaculated twice per week during a 12-week period to examine semen production and characteristics. The results suggest that supplementation of boar diets with CLA did not affect the spermatozoa fatty acid profile, semen volume, sperm concentration, viability, or motility, nor did it cause abnormal sperm morphology. Compared to controls, boars fed a CLA diet had a higher seminal pH and increased backfat thickness. In summary, this study indicates that CLA addition in boar diet does not change the semen characteristics or fatty acid profile of spermatozoa; however, it increases backfat thickness in sexually mature boars.

Keywords: Semen quality; Backfat thickness; Testicular characteristics.

\section{Introduction}

Semen quality, including ejaculate volume, sperm concentration, and percentages of sperm mortality and abnormality, determines the economic value of boars. ${ }^{1}$ Polyunsaturated fatty acids (PUFAs), mainly $\omega-3$ and $\omega-6$ acids, are abundant in the plasma membrane of boar spermatozoa ${ }^{2}$ and provide the sperm plasma mem-

\section{Cite this as:}

Zamora-Zamora V, Figueroa-Velasco JL, Cordero-Mora JL, Nieto-Aquino R, GarcíaContreras AC, Sánchez-Torres MT, Carrillo-Domínguez S, Martínez-Aispuro JA. Conjugated linoleic acid supplementation does not improve boar semen quality and does not change its fatty acid profile. Veterinaria México OA. 2017;4(3). doi: 10.21753/vmoa.4.3.387. 
brane, and the fluidity that it needs to participate in the events of membrane fusion associated with fertilization. ${ }^{3}$ The intake of different types and sources of PUFAs in males can affect the fatty acid composition and quality of semen, hormone levels, oxidative stress and physiological function of the testicle. ${ }^{4,5}$ Nevertheless, there are inconsistent results for supplementing boar diets with $\omega-3$ and $\omega-6$ as a strategy to improve the quality of seminal doses. Dietary $\omega-3$ and $\omega-6$ supplementation increased membrane-intact spermatozoa ${ }^{6}$ and contributed to greater progressive sperm motility and antioxidant capacity. ${ }^{1}$ Other studies suggested that supplementing the diet with oil rich in $\omega-3$ and $\omega-6$ modified the fatty acid composition of the sperm plasma membrane, increased the number of sperm cells in boar ejaculate, decreased the percentage of spermatozoa with abnormal morphologies, and altered some characteristics of their sexual behaviour.7, 8

Conjugated linoleic acids (CLAs) are PUFAs that are positional and geometric isomers of linoleic acid (C18:2), which are related to various health-giving properties for animals. In synthetic CLA preparations, the most biologically active and abundant isomers are cis-9, trans- $11,{ }^{9}$ and trans- 10 , and cis- $12 .{ }^{10}$ In humans, CLAs possess anticarcinogenic, ${ }^{9}$ antiatherogenic, ${ }^{11}$ and antidiabetogenic activities ${ }^{12}$ and regulate energy metabolism and immune responses. ${ }^{13}$ In pigs, CLA has demonstrated antioxidant activity ${ }^{14}$ and may be responsible for changes in whole-body fat deposition. ${ }^{15}$ The addition of CLA to pig diets modified the type and concentration of other fatty acids and increased the concentration of CLA in the meat. ${ }^{16}, 17$

Currently, the effects of CLA on the reproduction of domestic animals are poorly known, and research has been performed mainly on females. ${ }^{18}, 19$ Therefore, it is not known whether supplementation of the diet with CLA affects semen composition and quality in boars. To clarify whether dietary CLA affects the semen quality of boars, we performed an experiment to evaluate the effect of CLA addition to the diet on the semen characteristics of boars, including the fatty acid profile of sperm, as well as its effects on the carcass (backfat thickness and longissimus muscle area and testicles area).

\section{Materials and methods}

Experimental procedures were performed in accordance with the recommendations of the International Guiding Principles for Biomedical Research Involving Animals 20 and complied with Mexican law (NOM-062-Z00-1999) for the use of animals in experimentation. ${ }^{21}$ This research was performed at the Experimental Farm of the Colegio de Postgraduados, Montecillo Campus, located in Texcoco, Mexico State. During the experiment, animals were exposed to the ambient temperatures of October 2008 to January 2009, when the minimum and maximum temperatures were 13.5 and $26.3^{\circ} \mathrm{C}$, respectively.

\section{Animals and treatments}

Ten sexually active, terminal line boars (Yorkshire $\times$ Landrace $\times$ Pietrain), $232 \pm 12.3 \mathrm{~kg}$ body weight and 23 months old, were randomly assigned to one of two treatments. After a four-week adaptation, boars were randomly assigned to one of two experimental treatments, consisting of two levels of CLA 
(0 and $1 \%$; LutaCLA ${ }^{\circledR}$ 60, BASF Mexicana S.A. de C.V., Altamira, Tamaulipas, Mexico) mixed in standard diets for boars (Table 1). The diet was formulated based on sorghum-soybean meal to reach the recommended levels of the National Research Council.22

Data were collected in five replicates per treatment for 12 weeks. However, only data for weeks $0,4,8$ and 12 were considered for analysis (two treatments $\times 5$ boars $\times$ three observations by boar $=30$ ). Boars were individually housed in pens of $4.80 \mathrm{~m}^{2}$ with a concrete floor and equipped with nipple drinkers. The animals had free access to water, and the food was restricted, with $2.8 \mathrm{~kg} \mathrm{~d}^{-1}$ offered on the floor of the pen.

\section{Semen collection}

During the experiment, boars were induced to ejaculate twice per week. Semen was collected using the gloved-hand technique. ${ }^{23}$ After each boar ejaculated, the total volume was recorded, and the gel fraction was weighed. The sperm-rich fraction was separated from the gel fraction using filter bags for boar semen collection (U.S. Bag ${ }^{\text {TM }}$ System, Minitube, Mexico). Semen was maintained at $37^{\circ} \mathrm{C}$ in a water bath for evaluation.

\section{Evaluation of semen}

The sperm count per millilitre $(\mathrm{mL})$ was determined using a Neubauer chamber. To count the sperm, semen was diluted at a ratio of $1: 200$ with a solution of sodium citrate $3 \%$ formalin ( $3 \mathrm{~mL}$ formalin in 1,000 $\mathrm{mL}$ of double distilled water). Spermatozoa were counted in 5 of the 25 frames of the Neubauer chamber. ${ }^{24}$ Sperm motility was evaluated by placing a drop of semen on a slide prewarmed to 37 ${ }^{\circ} \mathrm{C}$, which was observed under an optical microscope at 400x. Total sperm motility was determined as the percentage of sperm that showed any signs of motility or movement in two areas of measurement by counting 100 cells per area. ${ }^{25} \mathrm{The} \mathrm{pH}$ of the semen was measured on a sample of $20 \mathrm{~mL}$ of semen, immediately after ejaculation, using a portable potentiometer (Orion, Model: 265, Orion Research, Inc. Germany).

\section{Sperm viability and morphology}

Assessment of sperm viability was performed using semen smears stained with eosin-nigrosin. ${ }^{26}$ Sperm morphology was evaluated using sperm smears stained with Bengal rose. Smears stained with eosin-nigrosin and Bengal rose were evaluated by counting 200 sperm per smear with an optical microscope at 400x. Viable sperm were defined as those that did not stain. Sperm morphology was evaluated by quantifying the proportion of sperm with an abnormal head, tail, middle part, or the presence of cytoplasmic droplets. ${ }^{27}$ Individual sperm abnormalities were added to obtain a single value of sperm cell abnormalities per ejaculate.

\section{Carcass and testicular characteristics}

From the beginning of the experiment and at weeks 4, 8 and 12 of the experimental period, backfat (BF) thickness and longissimus muscle area (LMA) were 
Table 1. Composition of experimental diets

\begin{tabular}{|c|c|c|}
\hline Treatment & Control & $1 \%$ CLA \\
\hline \multicolumn{3}{|l|}{ Ingredient, \% } \\
\hline Sorghum grain & 82.08 & 82.08 \\
\hline Soybean meal (44\%) & 12.44 & 12.44 \\
\hline Crude soybean oil & 1.52 & 0.52 \\
\hline $\mathrm{CLA}^{*}$ & 0.00 & 1.00 \\
\hline L-Lysine. $\mathrm{H}_{2} \mathrm{SO}_{4}{ }^{* *}$ & 0.33 & 0.33 \\
\hline DL-Methionine & 0.03 & 0.03 \\
\hline L-Threonine & 0.10 & 0.10 \\
\hline Vitamin Premix ${ }^{\dagger}$ & 0.20 & 0.20 \\
\hline Trace Mineral Premix $\rrbracket$ & 0.15 & 0.15 \\
\hline Antioxidant & 0.02 & 0.02 \\
\hline Calcium carbonate & 1.07 & 1.07 \\
\hline Orthophosphate & 1.56 & 1.56 \\
\hline Salt & 0.50 & 0.50 \\
\hline Total & 100.00 & 100.00 \\
\hline \multicolumn{3}{|l|}{ Calculated content, \% } \\
\hline Metabolizable energy, Mcal kg-1 & 3.265 & 3.265 \\
\hline Crude protein & 13.00 & 13.00 \\
\hline Calcium & 0.75 & 0.75 \\
\hline Available phosphorus & 0.40 & 0.40 \\
\hline Lysine & 0.70 & 0.70 \\
\hline Methionine & 0.24 & 0.24 \\
\hline Methionine+cystine & 0.47 & 0.47 \\
\hline Threonine & 0.57 & 0.57 \\
\hline Tryptophan & 0.13 & 0.13 \\
\hline \multicolumn{3}{|l|}{ Determined content, \% } \\
\hline Gross energy, Mcal kg-1 & 3.93 & 3.94 \\
\hline Crude protein & 13.50 & 13.32 \\
\hline Calcium & 0.92 & 0.90 \\
\hline Total Phosphorus & 0.65 & 0.64 \\
\hline
\end{tabular}

*Conjugated linoleic acid (LutaCLA® 60; BASF Mexicana S.A. de C.V.) contains: cis-9, trans-11 isomers, 30\%; trans-10, cis-12 isomers, 30\%; other isomers, $\leq 1 \%$; oleic acid, 22\%; palmytic acid, 6\%; stearic acid, 4\%; linoleic acid, 2\%; methanol, $\leq 100$ ppm; heavy metals. **BioLys contains: CP, 75\%; lysine, 50.70\%. †Each kg of feed supplied: vit. A, 15000 Ul; vit. D3, 2500 UI; vit. E, $37.5 \mathrm{Ul}$; vit. K, $2.5 \mathrm{mg}$, thiamine, $2.25 \mathrm{mg}$; riboflavin, $6.25 \mathrm{mg}$; niacin, $50 \mathrm{mg}$; pyridoxine, $2.5 \mathrm{mg}$; cyanocobalamin, 0.0375 mg; biotine, $0.13 \mathrm{mg}$; choline, $563 \mathrm{mg}$; pantothenic acid, $20 \mathrm{mg}$; folic acid, $1.25 \mathrm{mg}$. IEach kg of feed supplied: Fe, $150 \mathrm{mg}$; Zn, 150 mg; Mn, 150 mg; Cu, 10 mg; Se, 0.15 mg; I, 0.9 mg; Cr, 0.2 mg. 
measured at the tenth rib level using a real-time ultrasound Sonovet 600 with a $3.5 \mathrm{MHz}$ transducer (Medison, Inc., Cypress, California, USA). Additionally, the cross-sectional area $\left(\mathrm{cm}^{2}\right)$ in the right (RTA) and left (LTA) testicles, at approximately the middle of the testis, was measured using the same ultrasound.

\section{Laboratory analysis}

Samples of sperm cells at weeks $0,4,8$ and 12 for each boar were collected for fatty acid analysis. The semen was centrifuged at $1,500 \mathrm{~g}$ for $20 \mathrm{~min}$ at $4{ }^{\circ} \mathrm{C}$ to separate sperm cells from seminal plasma. After separation, sperm cells were resuspended with $50 \mathrm{~mL}$ of a solution containing BTS (Beltsville Thawing Solution; Minutube, Mexico) and then recentrifuged. The washed sperm cells were stored at $-20{ }^{\circ} \mathrm{C}$ for fatty acid analysis.

Determination of total lipids in sperm cells and experimental diets was performed following the 923.07 method of AOAC $2000 .{ }^{28}$ Saponification of the total lipids was performed with $2 \%$ methanolic sodium hydroxide, using myristoleic acid (Sigma-Aldrich Co., USA) as internal standard for gas chromatographic analysis. Trans-esterification to methyl esters of the lipids in sperm cells and diets was performed according to the 969.33 method of the AOAC 2000, ${ }^{28}$ using boron trifluoride-methanol (Sigma-Aldrich Co., USA). Fatty acids were identified and quantified by gas chromatography on a Varian 3400 CX chromatograph, equipped with an autosampler and a flame ionization detector (Varian Inc., CA, USA) using $\mathrm{N}_{2}$ as the carrier gas at axm flow of $30 \mathrm{~mL} \mathrm{~min}{ }^{-1}$. Temperatures used for chromatography were as follows: column, $230{ }^{\circ} \mathrm{C}$; injector, $150{ }^{\circ} \mathrm{C}$; and detector, $300{ }^{\circ} \mathrm{C}$ for fatty acids. Fatty acid methyl esters were identified by retention times relative to a standard mix (FAME mix C4-C24. Sigma Aldrich Co., MO, USA). CLA isomers were identified using a methyl ester standard that contained an acid mix of cis-9, trans-11; trans-9, cis-11; trans-10, cis-12; cis-10, and trans-12. (Cat. No. 05632, Sigma Aldrich Co., MO, USA). The fatty acid concentration of the samples was calculated using the area under the curve relative to the known standard.

The experimental diets were analysed in the laboratory to determine the concentration of crude protein using the Kjeldahl method ${ }^{29}$. Gross energy was measured in an adiabatic calorimeter bomb (Oxygen Bomb Calorimeter, Parr Instruments Co. Illinois, USA), following the methodology of Tejada ${ }^{30}$, and calcium and total phosphorus were measured by atomic absorption spectrophotometry (Varian Spectrophotometer SpectrAA 10 plus, Varian, Australia) following the methodologies of Fick et al. ${ }^{31}$

\section{Statistical Analysis}

Before analyses, the Shapiro-Wilk and Levene's test were used to corroborate the normal distribution and variance homogeneity of the variables data. The experimental design was a completely randomized design with treatment, week and interaction (treatment $\times$ week) as fixed effects, and the boar as random effect. Differences between treatments in the fatty acid profile of sperm cells, seminal characteristics, carcass and testicular characteristics were analysed using the mixed effect tests of SAS, ${ }^{32}$ in which initial values of the fatty acid profiles of sperm cells, seminal, carcass and testis characteristics were used as covariates for the statistical analysis 
Table 2. Fatty acid profile in experimental diets

\begin{tabular}{|c|c|c|}
\hline $\begin{array}{c}\text { Fatty acid } \\
\text { (Fatty acid methyl esters, \%) }\end{array}$ & Control & 1\% CLA \\
\hline Oleic (C18:1; n-9) & 29.16 & 28.05 \\
\hline Linoleic (C18:2; n-6) & 47.30 & 38.20 \\
\hline a-linolenic (C18:3; n-3) & 3.91 & 2.64 \\
\hline CLA; cis-9, trans-11 & N.D. & 7.84 \\
\hline CLA; trans-10, cis-12 & N.D. & 7.82 \\
\hline Arachidonic (C20:0) & 0.26 & 0.44 \\
\hline Eicosaenoic (C20:1; n-9) & 0.31 & 0.32 \\
\hline Eicosapentaenoic (EPA; C20:5; n-3) & 0.24 & 0.30 \\
\hline Lignoceric (C24:0) & 0.14 & 0.14 \\
\hline Saturated fatty acids & 16.63 & 13.08 \\
\hline Monounsaturated fatty acids & 30.44 & 29.43 \\
\hline Polyunsaturated fatty acids & 51.45 & 56.80 \\
\hline
\end{tabular}

N.D. $=$ non detectable.

of its corresponding variable for each boar. To determine the effect of CLA intake, time and the interaction between CLA and time, orthogonal linear and quadratic polynomials were used. ${ }^{33}$ Statistical significance of the results was set at $\mathrm{P} \leq 0.05$.

\section{Results and discussion}

In this experiment, it was assumed that a period of 84 days of experimental diet intake was sufficient to observe and confirm the effects of the intake of CLA on sperm quality and to maximize the incorporation of long-chain fatty acids into the plasma membranes of sperm. This was supported by the duration of spermatogenesis, which lasts between 39 and 40 days and because spermatozoa spends 9 to 12 days in passing through the epididymis of the boar. ${ }^{34}$ Furthermore, the effects of supplementing the boar diet were observed after 56 days. ${ }^{8}$

\section{Fatty acid profile of oils and experimental diets}

Analysis of the fatty acid profile of the experimental diets (Table 2) shows that diets with $1 \%$ CLA had $7.84 \%$ and $7.82 \%$ of the isomers cis-9, trans- 11 and trans-10, cis-12, respectively. These isomers were not detected in the control diet.

\section{Seminal characteristics (Table 3)}

Only the semen $\mathrm{pH}$ was affected by the CLA diet (linear effect, $\mathrm{P}=0.010$ ). Over time, a decrease in seminal $\mathrm{pH}$ was observed in both treatments (linear effect, $\mathrm{P}=0.001)$. The semen $\mathrm{pH}$ of boars fed the control diet showed a greater decrease (linear effect, $P=0.001$ ). The semen volume increased from week 4 to 8 , showing a reduction at week 12 of the experiment (quadratic effect, $P=0.044$ ). Changes in semen volume affected the sperm count per $\mathrm{mL}$, with a greater concentration of sperm per $\mathrm{mL}$ when the volume of semen decreased (quadratic effect, $\mathrm{P}=0.044$ ). 
Table 3. Seminal characteristics of boars fed diets supplemented with CLA

$(n=30$; error degrees of freedoms $=24)$

\begin{tabular}{|c|c|c|c|c|c|c|c|c|c|c|c|c|}
\hline Treatment & & \multicolumn{3}{|c|}{ Control } & \multicolumn{3}{|c|}{$1 \%$ CLA } & \multirow[b]{2}{*}{ SEM† } & \multirow[b]{2}{*}{ SEM ${ }^{\ddagger}$} & \multicolumn{3}{|c|}{$\begin{array}{c}\text { Significance } \\
\text { (P- value) }\end{array}$} \\
\hline Week & $0^{*}$ & 4 & 8 & 12 & 4 & 8 & 12 & & & $\mathbf{T}$ & W & $\mathrm{T} \times \mathrm{W}$ \\
\hline Seminal volume, mL & 324.40 & 396.20 & 417.00 & 408.75 & 346.95 & 398.90 & 304.10 & 37.90 & 27.50 & NS & $0.041(\mathrm{Q})$ & NS \\
\hline Gel fraction, g & 45.20 & 56.37 & 62.97 & 63.37 & 52.13 & 61.58 & 53.33 & 5.76 & 4.37 & NS & NS & $0.03(\mathrm{Q})$ \\
\hline \multicolumn{13}{|c|}{ Sperm concentration: } \\
\hline $\mathrm{mL}, 1 \times 10^{8}$ cells & 2.19 & 2.15 & 1.99 & 2.42 & 2.16 & 2.22 & 2.47 & 0.27 & 0.20 & NS & $0.009(L)$ & NS \\
\hline Total, $1 \times 10^{10}$ cells & 6.71 & 6.85 & 6.89 & 8.49 & 7.95 & 8.60 & 8.21 & 0.86 & 0.56 & NS & $0.038(L)$ & $0.045(Q)$ \\
\hline Viability, \% & 91.65 & 94.92 & 96.81 & 96.71 & 94.86 & 97.40 & 97.08 & 0.24 & 0.27 & NS & $0.001(L)$ & NS \\
\hline Progressive motility, \% & 89.50 & 89.57 & 89.06 & 89.57 & 89.68 & 90.18 & 89.93 & 0.67 & 0.54 & NS & NS & NS \\
\hline Abnormal morphology, \% & 9.10 & 7.19 & 5.09 & 4.94 & 7.34 & 5.11 & 4.76 & 1.13 & 0.87 & NS & $0.001(L)$ & NS \\
\hline Seminal pH & 7.34 & 7.30 & 7.23 & 7.14 & 7.37 & 7.32 & 7.29 & 0.02 & 0.01 & $0.01(\mathrm{~L})$ & $0.001(L)$ & NS \\
\hline
\end{tabular}

*Initial values used as covariates. ${ }^{\dagger}$ Standard error of the mean for treatments; ${ }^{\ddagger}$ Standard error of the mean for weeks. $\mathrm{T}=$ treatment; $\mathrm{W}=$ week; $\mathrm{T} \times \mathrm{W}=$ interaction between treatment and week.

Effects: $L=$ linear; $Q=$ quadratic; $N S=$ non significant. 
Furthermore, the overall sperm concentration improved during the experimental period (linear effect, $P=0.009$ ), with a greater increase in the total concentration of sperm in pigs fed the control diet (quadratic effect, $P=0.038$ ). The sperm viability improved (linear effect, $P=0.001$ ), whereas the number of cells with an abnormal morphology decreased (linear effect, $\mathrm{P}=0.001$ ).

No changes in seminal characteristics were observed due to CLA intake, similar to other studies in boars in which PUFAs supplementation had no effect on semen quality. ${ }^{35,} 36$ However, other experiments supplementing boar diets with PUFAs $\omega-3$ and $\omega-6$ improved the quality of seminal characteristics, modifying the fatty acid composition of the sperm. 1, 6,7 Although seminal characteristics were not affected by CLA intake during the experimental period, the increase in sperm concentration and viability and the decrease in abnormal morphology may be related to seasonal changes in temperature. Previous studies performed in colder months suggested that during the cooler months of the year, sperm count and semen production improved, ${ }^{37}$ and sperm abnormalities were fewer in pigs housed in cool temperatures. $^{38}$ In our study, seminal pH was the only variable affected by diet and time. This indicates that CLA intake can affect the secretions of the prostate, seminal vesicles and Cowper's gland, suggesting that CLA facilitate the good health of these glands. ${ }^{37}$

\section{Fatty acid profile in sperm cells}

The fatty acid profiles of sperm are presented in Table 4. The total concentration of saturated fatty acids (SFAs), monounsaturated fatty acids (MUFAs) and PUFAs was not affected by adding CLA to the diet $(P>0.05)$. Only the concentration of PUFAs was affected by time (quadratic effect, $P=0.008$ ). During the experimental period, the concentration of eicosatrienoic $(P=0.001)$, arachidonic $(P=0.001)$, and docosahexaenoic $(P=0.047)$ acids, as well as the total concentration of $n-3$ fatty acids $(P=0.018)$, had a quadratic relationship with time, showing a decrease of these fatty acids at week 8 , and either an increase in concentration at week 12 or similar to the values at the fourth week, whereas the concentration of total n- 6 fatty acids increased over time $(P=0.050)$. Furthermore, the relationship between the n- 6 and n-3 fatty acids (quadratic effect, $P=0.043$ ) and the relationship between docosahexaenoic and docosapentaenoic acids (linear effect, $P=0.038$ ) showed the same behaviour as the total n- 6 fatty acids.

No changes in the fatty acid profile of boar semen with supplementation of CLA in this study were observed. In most animal species, the fatty acid profile in sperm and semen reflects fatty acid intake. ${ }^{5}$ Specifically, pigs are effective in transferring fatty acids from the diet to the germ cells. ${ }^{6,7}$

Previous studies found that the fatty acid composition of sperm was modified with PUFAs supplementation 6, 8, 36, suggesting that PUFAs supplementation changes the lipid composition of the semen of boars. However, our results were contrary to these findings, and these differences may be due to the breeds used in the experiments. Yeste et al. noted that breed differences in boars fed with omega-3 could explain controversial reports in the literature, ${ }^{39}$ and may be related to differences in the composition of plasma membranes among breeds reported by other authors. They did not find negative effects in the three breeds evaluated (Duroc, Large-White and Pietrain) and found only positive effects in sperm quality 
Table 4. Fatty acid profile of boar spermatozoa ( $\mathrm{g}$ per $100 \mathrm{~g}$ of total lipids)

$(n=30$; error degrees of freedom $=24)$

\begin{tabular}{|c|c|c|c|c|c|c|c|c|c|c|}
\hline \multirow{2}{*}{$\begin{array}{c}\text { Treatment } \\
\text { Week }\end{array}$} & \multirow[b]{2}{*}{ 0* } & \multicolumn{3}{|c|}{ Control } & \multicolumn{3}{|c|}{$1 \%$ CLA } & \multirow[b]{2}{*}{ SEM $^{\dagger}$} & \multirow[b]{2}{*}{ SEM $¥$} & \multirow{2}{*}{$\begin{array}{c}\begin{array}{c}\text { Significance } \\
\text { (P-value) }\end{array} \\
\text { W }\end{array}$} \\
\hline & & 4 & 8 & 12 & 4 & 8 & 12 & & & \\
\hline \multicolumn{11}{|l|}{ Fatty acids } \\
\hline Total SFAs & 31.13 & 26.33 & 29.20 & 26.89 & 29.62 & 32.01 & 28.73 & 1.12 & 1.16 & NS \\
\hline Total MUFAs & 18.15 & 15.86 & 14.98 & 13.82 & 14.96 & 16.89 & 16.35 & 1.27 & 1.45 & NS \\
\hline Total PUFAs & 44.85 & 45.77 & 45.56 & 51.97 & 49.85 & 41.54 & 49.76 & 1.64 & 1.86 & $0.008(\mathrm{Q})$ \\
\hline $\mathrm{C} 18: 2 ; \omega-6$ & 3.81 & 4.04 & 4.08 & 2.56 & 2.92 & 4.75 & 3.49 & 0.48 & 0.59 & NS \\
\hline CLA; cis-9, trans-11 & N.D. & N.D. & N.D. & N.D. & N.D. & N.D. & N.D. & N.D. & N.D. & --- \\
\hline CLA; trans-10, cis- 12 & N.D. & N.D. & N.D. & N.D. & N.D. & N.D. & N.D. & N.D. & N.D. & --- \\
\hline $\mathrm{C} 20: 3 ; \omega-6$ & 1.00 & 1.32 & 0.84 & 1.39 & 1.21 & 0.42 & 1.25 & 0.16 & 0.15 & $0.001(\mathrm{Q})$ \\
\hline $\mathrm{C} 20: 4 ; \omega-6$ & 2.13 & 2.34 & 2.12 & 2.54 & 2.42 & 1.91 & 2.55 & 0.11 & 0.12 & $0.001(\mathrm{Q})$ \\
\hline $\mathrm{C} 22: 5 ; \omega-6$ & 22.35 & 25.41 & 26.43 & 31.34 & 24.12 & 21.25 & 25.58 & 2.54 & 1.99 & $0.047(\mathrm{~L})$ \\
\hline $\mathrm{C} 22: 6 ; \omega-3$ & 15.35 & 14.61 & 13.70 & 15.60 & 17.18 & 10.91 & 14.09 & 1.11 & 1.08 & $0.018(Q)$ \\
\hline Total $\omega-3$ & 15.49 & 14.61 & 13.70 & 15.87 & 17.18 & 10.91 & 14.47 & 1.14 & 1.09 & $0.018(Q)$ \\
\hline Total $\omega-6$ & 29.36 & 33.38 & 34.07 & 38.25 & 30.51 & 28.41 & 33.07 & 2.06 & 1.59 & $0.050(\mathrm{~L})$ \\
\hline$\omega-6: \omega-3$ & 2.20 & 2.66 & 2.76 & 2.66 & 1.94 & 2.58 & 2.41 & 0.28 & 0.22 & $0.043(\mathrm{Q})$ \\
\hline $\mathrm{C} 22: 5 \omega-6: \mathrm{C} 22: 6 \omega-3$ & 1.67 & 1.99 & 2.20 & 2.30 & 1.48 & 1.89 & 1.87 & 0.24 & 0.17 & $0.038(L)$ \\
\hline
\end{tabular}

*Initial values used as covariates. ${ }^{\dagger}$ Standard error of the mean for treatments; ${ }^{\ddagger}$ Standard error of the mean for weeks. $\mathrm{W}=$ week; SFAs $=$ saturated fatty acids; MUFAs $=$ monounsaturated fatty acids; PUFAs $=$ polyunsaturated fatty acids; N.D. $=$ non-detectable.

Effects: $\mathrm{L}=$ linear; $\mathrm{Q}=$ quadratic; $\mathrm{NS}=$ non-significant. 
in Large-White and Pietrain boars. The authors concluded that omega-3 fatty acids may improve sperm quality; however, this depends on the boar breed. These controversial results may be due to variations in the quantities and sources of oil and the duration of supplementation.

\section{Carcass and testicular characteristics}

For carcass and testicular characteristics (Table 5), the intake of CLA linearly increased the backfat thickness $(P=0.008)$. No differences were found between treatments during the course of the experiment (linear effect, $\mathrm{P}=0.045$ ), but backfat accumulation occurred with lower intensity in pigs fed the control diet. Furthermore, the LMA increased (linear effect, $\mathrm{P}=0.011$ ) only as an effect of time. Regarding the transverse testicular area, although this characteristic was not affected by CLA intake ( $P>0.05)$, there was an increase in cross-sectional area of both testicles during the experimental period. The decrease in seminal volume and number of total cells in the CLA diet animals, considering that these animals showed an increase in testicle area, could be due to CLA addition increasing lipid peroxidation. This is due to the observation that higher linoleic acid can cause the cascade reaction of lipid peroxidation and DNA damage of spermatozoa. ${ }^{40}$

The greatest accumulation of backfat observed in pigs fed CLA diets is inconsistent with the findings in growing-finishing animals, in which inclusion of $0.5 \%$ CLA in diets produced no change in backfat thickness. ${ }^{16,41}$ By contrast, the addition of $4 \%$ CLA tended to reduce backfat in gilts. ${ }^{42}$ Due to high levels of dietary PUFAs, they may promote lipid peroxidation and limit the viability and motility of spermatozoa. ${ }^{43}$ There is evidence that CLA may inhibit the proliferation and/or differentiation of adipose cells and the synthesis and accumulation of triglycerides in adipocytes, decreasing body fat deposition. ${ }^{44}$

With respect to LMA, the results are consistent with those of Mirand et al, 45 which indicate that the intake of CLA in adult animals does not change the body composition. Moreover, the increased cross-sectional area of the testes during the experimental period may be due to the increased production of semen.

\section{Conclusion}

Adding derivatives of $\omega 6$ (conjugated linoleic acid) to boar diets did not change semen characteristics or fatty acid profiles of spermatozoa; however, it increased backfat thickness in sexually mature boars. 
Table 5. Carcass and testicular characteristics of boars fed CLA supplemented diets

$(n=30$; error degrees of freedom $=24)$

\begin{tabular}{|c|c|c|c|c|c|c|c|c|c|c|c|}
\hline \multirow{2}{*}{$\begin{array}{c}\text { Treatment } \\
\text { week }\end{array}$} & \multirow[b]{2}{*}{ 0* } & \multicolumn{3}{|c|}{ Control } & \multicolumn{3}{|c|}{$1 \%$ CLA } & \multirow[b]{2}{*}{ SEM' } & \multirow[b]{2}{*}{ SEM ${ }^{\ddagger}$} & \multicolumn{2}{|c|}{$\begin{array}{c}\text { Significance } \\
\text { (P-value) }\end{array}$} \\
\hline & & 4 & 8 & 12 & 4 & 8 & 12 & & & $T$ & w \\
\hline $\mathrm{BF}, \mathrm{mm}$ & 12.30 & 10.82 & 10.57 & 11.37 & 13.08 & 13.23 & 14.08 & 0.80 & 0.58 & $0.008(\mathrm{~L})$ & $0.045(L)$ \\
\hline LMA, $\mathrm{cm}^{2}$ & 41.49 & 41.84 & 41.59 & 43.33 & 43.42 & 44.50 & 45.25 & 2.00 & 1.40 & NS & $0.011(\mathrm{~L})$ \\
\hline RTA, $\mathrm{cm}^{2}$ & 61.95 & 50.40 & 53.72 & 52.69 & 49.80 & 53.45 & 55.77 & 1.14 & 0.93 & NS & $0.018(\mathrm{~L})$ \\
\hline LTA, $\mathrm{cm}^{2}$ & 60.97 & 49.54 & 52.50 & 52.09 & 51.66 & 54.67 & 54.29 & 1.53 & 1.19 & NS & $0.013(\mathrm{Q})$ \\
\hline
\end{tabular}

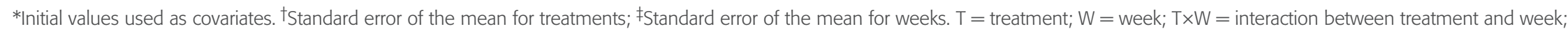
$\mathrm{BF}=$ backfat thickness; $\mathrm{LMA}=$ longissimus muscle area; RTA = right testicle area; LTA $=$ left testicle area.

Effects: $\mathrm{L}=$ =linear; $\mathrm{Q}=$ quadratic; $\mathrm{NS}=$ non-significan 


\section{Funding}

Programa de Ganadería, Campus Montecillo, Colegio de Postgraduados, Texcoco, Estado de México, 56230, México.

\section{Conflicts of interest}

The authors declare that there are no conflicts of interest related to the publication of this article.

\section{Author contributions}

Dr. Vicente Zamora-Zamora: designed the initial proposal, did the experimental work; did the laboratory and statistical analysis of data; wrote the first draft of manuscript.

Dr. José Luis Figueroa-Velasco: designed, directed and supervised the research; revised all versions of manuscript.

MVZ. José Luis Cordero-Mora: collaborated with proposal set, experimental work; supervised health status of pigs; obtained samples and data from pigs; revised final version of manuscript.

Dr. Rafael Nieto-Aquino: participated in the experimental design; supervision of experimental protocol; supervision and support to take samples and data from pigs; revised final version of manuscript.

Dra. Adelfa del C. García-Contreras: revised research proposal and final manuscript.

Dra. María Teresa Sánchez-Torres: revised research proposal, revised final version of proposal and final manuscript.

Dra. Silvia Carrillo-Dominguez: collaborated with laboratory analysis. Revised research proposal and final manuscript.

Dr. José Alfredo Martínez-Aispuro: revised and corrected all versions of manuscript.

\section{References}

1. Liu Q, Zhou YF, Duan RJ, Wei HK, Jiang SW, Peng J. Effects of dietary n-6:n-3 fatty acid ratio and vitamin $\mathrm{E}$ on semen quality, fatty acid composition and antioxidant status in boars. Anim Reprod Sci. 2015;165:11-9. doi: 10.1016/j. anireprosci.2015.08.012.

2. Webel SK, Spencer JD, Gaines AM. The role of omega-3 and omega- 6 fatty acids in swine reproduction. J Anim Sci. 2007;85:401.

3. Wathes $D$, Abayasekara $D$, Aitken R. Polyunsaturated fatty acids in male and female reproduction. Biol Reprod. 2007;77:190-201. doi: 10.1095/ biolreprod. 107.060558.

4. Maldjian A, Pizzi F, Gliozzi T, Cerolini S, Penny P, Noble R. Changes in sperm quality and lipid composition during cryopreservation of boar semen. Theriogenology. 2005;63:411-21.

5. Esmaeili $V$, Shahverdi AH, Moghadasian $M H$, Alizadeh AR. Dietary fatty acids affect semen quality: a review. Andrology. 2015;3:450-61.

6. Strzeżek J, Fraser L, Kuklińska M, Dziekońska A, Lecewicz M. Effects of dietary supplementation with polyunsaturated fatty acids and antioxidants on biochemical characteristics of boar semen. Reprod Biol. 2004;4:271-87.

7. Lin $Y$, Cheng $X$, Mao J, Wu D, Ren $B, X u S$, et al. Effects of different dietary n-6/n-3 polyunsaturated fatty acid ratios on boar reproduction. Lipids Health Dis. 2016;15:31. doi: 10.1186/s12944-016-0193-8. 
8. Estienne MJ, Harper AF, Crawford RJ. Dietary supplementation with a source of omega-3 fatty acids increases sperm number and the duration of ejaculation in boars. Theriogenology. 2008;70:70-6.

9. Pariza MW, Park Y, Cook ME. The biologically active isomers of conjugated linoleic acid. Prog Lipid Res. 2001;40:283-98.

10. Park Y, Storkson JM, Albright KJ, Liu W, Pariza MW. Evidence that the trans-10, cis-12 isomer of conjugated linoleic acid induces body composition changes in mice. Lipids. 1999;34(3):235-41.

11. Nicolosi R, Rogers EJ, Kritchevsky D, Scimeca JA, Huth PJ. Dietary conjugated linoleic acid reduces plasma lipoproteins and artery aortic atherosclerosis in hypercholesterolemic hamsters. Artery. 1997;22:266-77.

12. Moloney F, Toomey S, Noone E, Nugent A, Allan B, Loscher CE, et al. Antidiabetic effects of cis-9, trans-11-conjugated linoleic acid may be mediated via anti-inflammatory effects in white adipose tissue. Diabetes. 2007;56:574-82. doi: 10.2337/db06-0384.

13. Kelley DS, Erickson KL. Modulation of body composition and immune cell functions by conjugated linoleic acid in humans and animal model: benefits vs. risks. Lipids. 2003;38(4):377-86. doi: 10.1007/s1 1745-003-1072-2.

14. Hur SJ, Park GB, Joo ST. A comparison of the effects of dietary conjugated linoleic acid contents, cholesterol, lipid oxidation and drip loss in pork loin and chicken breast. J Muscle Foods. 2007;18:264-75. doi: 10.1111/j.1745-4573.2007.00082.x.

15. Ostrowska E, Muralitharan M, Cross RF, Bauman DE, Dunshea FR. Dietary conjugated linoleic acids increase lean tissue and decrease fat deposition in growing pigs. J Nutr. 1999;129(11):2037-42.

16. Martínez-Aispuro M, Figueroa-Velasco JL, Zamora-Zamora V, Cordero-Mora JL, Narciso-Gaytán C, Sánchez-Torres MT, et al. Effect of CLA supplementation to low-protein diets on the growth performance, carcass characteristics, plasma urea nitrogen concentration, and fatty acid profile in the meat of pigs. Braz Arch Biol Technol. 2014;57(5):742-54. doi: 10.1590/S1516-8913201401407.

17. Ivanovic J, Pantic S, Dokmanovic M, Glamoclija N, Markovic R, Janjic J, et al. Effect of conjugated linoleic acids in pig nutrition on quality of meat. Procedia Food Sci. 2015;5:105-8. doi: 10.1016/j.profoo.2015.09.029.

18. Hadaš Z, Nevrkla P, Václavková E. Effect of conjugated linoleic acid on reproductive performance of gilts. J Agricultural Sci.7(6):120-6. doi: 10.5539/jas. v7n6p 120.

19. Castañeda-Gutiérrez E, Benefield BC, de Veth MJ, Santos NR, Gilbert RO, Butler $W R$, et al. Evaluation of the mechanisms of action of conjugated linoleic acid isomer on reproduction in dairy cows. J Dairy Sci. 2007;90(9):4253-64. doi: 10.3168/jds.2007-0117.

20. Council for International Organizations of Medical Sciences. International Guiding Principles for Biomedical Research Involving Animals. Geneva (CH) 1986.

21. Secretaría de Gobernación. [NOM-062-ZOO] Norma Oficial Mexicana. Especificaciones técnicas para la producción, cuidado y uso de los animales de laboratorio. México DF (MX): Diario Oficial de la Federación; 1999.

22. [NRC] National Research Council. Nutrient Requirements of Swine. 10th ed. Washington DC (US): National Academy Press; 1998.

23. Hancock JL, Hovell GJR. The collection of boar semen. Vet Rec. 1959;71:664-5. 
24. Ax RL, Dally MR, Didion BA, Lenz RW, Love CC, Varner DD, et al. Semen evaluation. In: E HES, B H, editors. Reproduction in farm animals. 7th ed. Baltimore (US): Wiley-Blackwell; 2000. p. 365-75.

25. Rodriguez-Gil JE, Rigau T. Effects of slight agitation on the quality of refrigerated boar semen. Anim Reprod Sci. 1995;39:141-6.

26. Tardif S, Laforest JP, Cornier N, Bailey JL. The importance of porcine sperm parameters on fertility in vivo. . Theriogenology. 1999;52:447-59.

27. Sorensen AM. Animal Reproduction: Principles and Practices. New York (US): McGraw-Hill Publishing Co; 1979.

28. Association of Official Analytical Chemists International. Official Methods of Analysis of AOAC International. 17th ed. Gaithersburg MD (US)2000.

29. Association of Official Analytical Chemists. Official Methods of Analysis. 15th ed. Washington D C (US) 1990.

30. Tejada HI. Análisis de granos y cereales. Control de Calidad y Análisis de Alimentos para Animales. México (MX): Sistema de Educación Continúa en Producción Animal, A.C.; 1992.

31. Fick KR, McDowell LR, Miles RH, Wilkins NS, Funk J, Conrad JH. Methods of Mineral Analysis of Plant and Animal Tissues. 2nd ed. Gainesville, FL (US): University of Florida; 1979.

32. SAS Institute. The SAS System, release 8.2 for Windows. North Carolina (US): Cary; 2009.

33. Steel RG, Torrie JH, Dickey DA. Principles and procedures of statistics: A biometrical approach. 3rd ed. New York (US): WCB McGraw-Hill Co; 1997.

34. França LR, Avelar GF, Almeida FFL. Spermatogenesis and sperm transit through the epididymis in mammals with emphasis on pigs. Theriogenology. 2005;63:300-18.

35. Paulenz H, Taugbøl O, Hofmo P, Saarem K. A preliminary study on the effect of dietary supplementation with cod liver oil on the polyunsaturated fatty acid composition of boar semen. Vet Res Commun. 1995;19:273-84.

36. Castellano CA, Audet I, Bailey JL, Chouinard PY, Laforest JP, Matte JJ. Effect of dietary n-3 fatty acids (fish oils) on boar reproduction and semen quality. J Anim Sci. 2010;88(7):2346-55. doi: 10.2527/jas.2009-2779.

37. Ciereszko A, Ottobre JS, Glogowski J. Effects of season and breed on sperm acrosin activity and semen quality of boars. Anim Reprod Sci. 2000;64(1-2):89-96.

38. Larsson K, Einarsson S. Seminal changes in boars after heat stress. Acta Vet Scandinavica. 1984;25:57-66.

39. Yeste $M$, Barrerab $X$, Collc $D$, Boneta $S$. The effects on boar sperm quality of dietary supplementation with omega-3 polyunsaturated fatty acids differ among porcine breeds. Theriogenology. $2011 ; 76(1): 184-96$. doi: 10.1016/j. theriogenology.2011.01.032.

40. J AR. Free radicals, lipid peroxidation and sperm function. Reprod Fertil Dev. 1995;7:659-68.

41. Lauridsen $\mathrm{C}, \mathrm{Mu} \mathrm{H}$, Henckel P. Influence of dietary conjugated linoleic acid (CLA) and age at slaughtering on performance, slaughter- and meat quality, lipoproteins, and tissue deposition of CLA in barrows. Meat Sci. 2005;69(3):393-9. doi: 10.1016/j.meatsci.2004.08.009.

42. Tous N, Lizardo R, Vilà B, Gispert M, Font-i-Furnols M, Esteve-Garcia E. Effect of a high dose of CLA in finishing pig diets on fat deposition and fatty acid compo- 
sition in intramuscular fat and other fat depots. Meat Sci. 2013;93:517-24. doi: 10.1016/j.meatsci.2012.10.005.

43. Surai PF, Noble RC, Sparks NH, Speake BK. Effect of long-term supplementation with arachidonic or docosahexaenoic acids on sperm production in the broiler chicken. J Reprod Fertil. 2000;120(2):257-64.

44. Qi R, Yang F, Huang J, Peng H, Liu Y, Liu Z. Supplementation with conjugated linoleic acid decreases pig back fat deposition by inducing adipocyte apoptosis. BMC Vet Res. 2014;10:141. doi: 10.1186/1746-6148-10-141.

45. Mirand PP, Arnal-Bagnard MA, Mosoni L, Faulconnier Y, Chardigny JM, Chilliard Y. Cis-9, trans-11 and trans-10, cis-12 conjugated linoleic acid isomers do not modify body composition in adult sedentary or exercised rats. J Nutr. 2004; 134:2263-9. 